did not respond, probably due to the lower temperatures. When a person stood perfectly quiet near a plant and a shadow was thrown on the weed, some of the leafhoppers immediately flew about. When an insect-net was moved about but without casting a shadow upon the plant, the bugs did not fly from the weed. Evidently the insects do not respond to a moving object but a shadow arouses some of them to activity.

Chatrman H. J. Quayle: I see Prof. Doane is here now. We will listen to his paper on "Weevils in Australian Wheat in California."

\title{
WEEVILS IN AUSTRALIAN WHEAT IN CALIFORNIA
}

By R. W. Dosne, Stanford Universily, California. Collaborator, Bureau of Entomology, U. S. Department Agriculture

The great demand for vessels of all kinds that came with the beginning of the late war soon interrupted the normal movement of foodstuffs in all parts of the world. In a very short time the serious results of this restricted movement began to be apparent in many quarters. Vast quantities of food that were badly needed elsewhere began to accumulate in certain centers where no provision was ever made to handle it in such unusual amounts.

One of the most serious situations brought about by this condition was the accumulation of millions of bushels of wheat in the Australian and New Zealand seaports, where most of it had to lay for many months; some for three or four years, awaiting shipment. It was inevitable that the weevils and other insects should take advantage of such an opportunity to wax fat and multiply.

I have not seen any account of the work that has been done in Australia in the efforts to control the weevils there, but I have had an opportunity to inspect much of the wheat that has come into San Francisco and Los Angeles from Australia, and to see the way in which the mills here handle the infested grain.

The wheat was imported by the Grain Corporation of the United States Food Commission, and sold to the mills that seemed to need it most. Most of it went to mills in San Francisco and Vallejo, but some went to Stockton and some to Los Angeles and vicinity, and smaller amounts to Oregon and Arizona. All of the mills receiving this wheat were working on government contracts, furnishing the government a certain amount of flour or other products. The Grain Corporation assumed no control over the wheat after it was taken from the docks by the mills. 
The first few lots of this wheat came on some of the steamers that ply regularly between San Francisco and Australia. These steamers make the trip in about twenty days. Most of the wheat, however, has been shipped on sailing vessels requiring eighty or ninety days or more to make the trip. I am told that one vessel was at sea nearly six months before it finally reached San Francisco.

Of course these long trips, mostly through tropical waters, give time for the wheat to become thoroughly warmed. Unfortunately we did not take any temperature tests in the holds of these vessels, but several times it was found that the wheat in the sacks would feel very warm and this heat would be retained for several hours after the sacks were stacked on the docks. So the number of insects in these cargoes was doubtless much greater when the ships reached San Francisco than when they left Australia, as conditions were almost ideal for their development. But the great amount of wheat that had been cut by the weevils and the masses of insects that were found on and throughout the sacks that came on the steamers in the earlier shipments, showed that most of the damage must have been done while the wheat was still in storage in Australia.

There was a great deal of difference in the amount of infestation in the different sacks in all of the shipments. Some sacks showed but little injury due to the beetles, in other sacks we would find 80 per cent to 90 per cent of the grain injured or destroyed by the weevils. A handful of the grain taken from the sack would sometimes contain from six to fifteen or more weevils. These badly infested sacks were usually covered with the beetles that were coming from the wheat, and the flour or dust from the injured grains was sifting through the exit holes made by the beetles.

In San Francisco most of this wheat was hauled from the docks to the mills and carried by conveyers directly to the bins where it was stored until needed. Usually the miller began to draw on this supply at once, for few, if any, of the companies had any reserve. Before the wheat was stored in the bins it passed through screens to take out the straws, unthrashed heads and other large rubbish. As it was drawn off for use it passed through suction cleaners that drew off the light grain, weed seeds, weevils, etc. These screenings were placed in sacks and disposed of in various ways. If they contained a good deal of grain they were often-sold for chicken or hog or sheep feed, or ground in the atrition mill for ground feed. Some of the lots that contained but little wheat and much smut and many beetles and weed seeds, were burned or thrown into the bay.

Although we all recognized that burning was the safest way to handle these screenings, it did not seem advisable to destroy the lots 
that contained a considerable amount of wheat that might be used for feed, especially if we could in some way destroy the beetles so they would not be a source of danger wherever the feed was used.

Carbon bisulphide could not be used for this purpose as the mills would not take the fire risk. Cyanide seemed to be out of the question as the screenings were so finely packed in the sacks that it would be very hard, if not impossible, to get sufficient penetration of the gas, unless the vacuum system was used and that was considered too expensive for the purpose.

We urged that all of the mills that were handling this wheat make some provision for treating the screenings with heat to destroy the insects and some of them complied with this request. One firm, instead of building a small room or partitioning off a small part of a large room, constructed a tight box 16 feet long, 5 feet high and 3 feet from front to back. The front side of the box was provided with eight doors which opened practically the whole side of the box. These doors were secured by fasteners which clamped them close to their frames when closed. There was shelf room for 16 sacks of wheat in this box. Close to the bottom were 28,9 -foot lengths of $3 / 4$-inch pipe. The cost of such a box including material and labor was about $\$ 200$. The engineer said that the cost of operating it was inconsiderable as it took but little steam to maintain the required temperature.

The sacks of screenings to be treated were placed in this box about 9 o'clock in the morning and left there until 3 or 4 o'clock of the sameday, sometimes they were left there until the next morning. The steam was turned on as soon as the box was filled and left until 4.30 or 5 o'clock in the evening.

An examination of the screenings that had been subjected to this treatment showed that, when the sacks were left in the box for only six or eight hours, all of the beetles were not killed, but when they were left in twelve hours or longer, no living insects could be found. A series of tests and experiments showed that with a steam pressure of 80 pounds the temperature in the box was raised to about $53^{\circ} \mathrm{C}$. in a very short time; with an increased pressure the temperature rises very rapidly. With 150 pounds pressure the thermometer soon read $90^{\circ}$ or $92^{\circ} \mathrm{C}$.

The weevils and other beetles that were on the outside of the sacks began to die when the temperature reached $50^{\circ}$ to $52^{\circ} \mathrm{C}$. and before it reached $60^{\circ} \mathrm{C}$. all that were exposed were dead. But it was found that the heat penetrates the screenings very slowly, so that after an exposure of six hours to a temperature of $53^{\circ}$ to $80^{\circ} \mathrm{C}$. a thermometer that had been placed in the center of the sack showed no increase of temperature. After about seven or eight hours the heat began to 
reach the center of the sack and in about twelve or fourteen hours the temperature would go as high as $53^{\circ}$ to $58^{\circ} \mathrm{C}$. while the temperature in the box outside the sacks would be $80^{\circ}$ to $90^{\circ} \mathrm{C}$. Under these conditions all the insects in the screenings were killed.

The screenings after being taken from the hot-box gave up their heat, seemingly, as slowly as they took it, for we found that the temperature in one of the sacks dropped only $3^{\circ} \mathrm{C}$. in five hours, although the sack was placed near an outside door in a cool store room.

The results of these experiments showed that with a box as described above and with a steam pressure of 80 to 150 pounds the screenings should be exposed to the heat twelve hours.

One of the Los Angeles mills built a small brick walled room about 6 feet by 10 feet by 8 feet high. It was heated by short coils of pipe on one side of the room 4 or 5 feet from the floor. The cost of building this room and installing the pipes was about $\$ 225$. The miller said that it took several hours to heat the room and that he had found it necessary to raise the temperature to $190^{\circ} \mathrm{F}$. $\left(88^{\circ} \mathrm{C}\right.$.) in order to kill the insects. The thermometer from which his readings were taken was placed on the wall near the steam coils and on the same level with them. Tests made with other thermometers showed that one placed on a level with the coils but some distance from them, soon reached $71^{\circ} \mathrm{C}$. Another placed about 2 feet from the floor, on a sack of screenings registered $48^{\circ} \mathrm{C}$. while a third that had been thrust into the center of the sack of screenings registered only $28^{\circ} \mathrm{C}$. This showed that the unusual and unsatisfactory results that were being obtained were due to the steam coils being placed high on the sides of the wall, instead of on the floor or very close to it. It is believed that when these coils are placed lower down, as recommended, no further trouble will be met with.

Some other mills have already installed, or propose to install, small heat rooms for treating infested flour or other material that may be returned to the mill from dealers or elsewhere.

One company has been spraying all of the Australian wheat received by its various mills with carbon tetrachloride. The work is done with small hand pumps and the wheat is sprayed as it is poured from the conveyers into the bins. The aim is to use about 2 gallons of the liquid to about 1000 bushels or 30 tons of the grain. In this way they figure that the cost of the material for treating a ton of grain is about 20 cents. If the bins in which wheat, that has been treated in this way, is stored, are tight and can be kept closed for a few days, nearly all of the weevils are killed. If the wheat is drawn from the bins within twenty-four or thirty-six hours after it has been treated, many live weevils are often found. The wheat should lie in the bin at least 
two or three days to insure satisfactory results. This company reports that careful tests show that the milling qualities of wheat treated in this way are not affected.

The Rice Weevil, Calandra oryzae, is the most common beetle found in all of the shipments of Australian wheat, that I have examined. In some lots the grain weevil, C. granaria, was also very abundant, in other shipments but few were found. The saw-toothed grain beetles, Silvanus surinamensis, were always abundant. The confused flour beetles, Tribolium confusum, were common in all shipments, and T. ferrugineum was also often quite common. The lesser grainborer, Rhizopertha dominica, was always quite abundant and apparently very destructive. The flat grain beetle, Laemophloeus minutus, was common in all lots. The cadelle, Tenebroides mauritanicus, and a few other beetles were more or less common.

Mesaporus calandrae How., the cosmopolitan parasite of grain weevils, was common on nearly all lots of Australian wheat examined and it was exceedingly abundant in some of the lots.

Chairman H. J. Quayle: There are a number of papers on file with the Secretary to be read. Inasmuch as the authors are not present to read these papers, I am going to ask the Secretary to read them by title only. They will be included in the proceedings and can be read by all of us at some future time.

\section{INVESTIGATIONS OF THE BEET LEAFHOPPER (EUTETTIX TENELLA BAKER) IN CALIFORNIA}

By Henry H. P. Severin, Ph.D., California Agricultural Experiment Station

\section{INTRODUCTION}

Where do the enormous numbers of beet leafhoppers (Eutettix tenella Baker), which invade the cultivated districts, come from in the spring? Where do the hoppers go in the autumn after leaving the cultivated area and where do they spend the winter? These are questions that have been asked repeatedly by agriculturists and have baffled scientists during the past thirteen years. Are there other plants from which the leafhoppers transmit curly leaf disease to sugar beets? These subjects and a consideration of the life history and related topics will receive attention.

In California, Dr. E. D. Ball (1), former director of the Utah Agricultural Experiment Station, endeavors to trace the origin of the pest in the beet fields through migrations from desert breeding areas in the 